\title{
SILENCIAMENTO E RESISTÊNCIA: RETRATOS DA MULHER NOS CONTOS FREIRIANOS
}

\author{
SILENCE AND RESISTANCE: WOMAN'S PORTRAITS IN \\ FREIRE'S TALES
}

\author{
Claudimar Paes de Almeida' \\ Leoné Astride Barzotto²
}

\begin{abstract}
RESUMO: A década de 1960 foi um momento precursor do pensamento feminista, pois a mulher se torna elemento de estudo em diversas áreas do conhecimento. Com esse pressuposto, o trabalho tem como objetivo realizar um estudo através dos contos de Marcelino Freire contidos nas obras BaléRalé (2004) e Contos negreiros (2005), acerca do pós-colonialismo, feminismo e a questăo de gênero, já que há um estreitamento entre estas correntes críticas, pois como afirma (DU PLESSIS, 1985, p. 46 apud BONNICI, 2009, p. 266) “Uma mulher da colônia é uma metáfora da mulher como colônia". Considera-se que, se o homem foi duramente colonizado, a mulher sentiu, em suas "entranhas", duplamente esse processo. Diante dos apontamentos, toma-se como metodologia um estudo crítico-analítico, apoiando-se em referências que contribuem diretamente nas ponderaçôes assinaladas. A pesquisa agrega os seguintes aportes teóricos: Adichie (2015), Beauvoir (1980), Bonnici (2009) e Zolin (2009). A análise ultimou que a figura feminina contemporânea ainda vivencia as muitas mazelas do contexto pós-colonialista, principalmente quando direcionadas ao silenciamento e ao subjugamento à violência, à prostituiçăo ou ao abuso sexual. Entretanto, as vozes de resistência da mulher à náo imposiçâo, julgamento e subalternidade salpicam como "gotas de sangue" na conjuntura atual.
\end{abstract}

Palavras-chave: Colonialismo; Contemporaneidade; Gênero; Marcelino Freire; Póscolonialismo.

ABSTRACT: The 60's were a precursor time of Feminist thought, for the woman becomes a study element in various areas of knowledge. Within this assumption, this study aims to conduct a study through Marcelino Freire's tales which are in the works BaléRalé (2004) and Contos negreiros (2005), considering Post-colonialism, Feminism and Gender Studies, as there is a narrowing between these critical currents because, as said (DU PLESSIS, 1985, p. 46 apud BONNICI, 2009, p. 266) "A colony of the woman is a woman of metaphor as a colony". It is considered that if the man was heavily colonized, the woman felt, in her "gut", doubly this process. On the notes, the methodology is based on a critical-analytical study, relying on references that contribute directly to

\footnotetext{
1 Universidade Federal da Grande Dourados / claudimarpaes@hotmail.com

2 Universidade Federal da Grande Dourados / leoneastridebarzotto@gmail.com
} 
the indicated concerns. The research adds the following theoretical contributions: Adichie (2015), Beauvoir (1980), Bonnici (2009) and Zolin (2009). The final analysis comprehends that the contemporary female figure is still experiencing the many ills of post-colonial context, especially when directed at silencing and subjugation to violence, prostitution or sexual abuse. However, the woman's resistance voices to the non-imposition scene, trial and subaltern dot as "drops of blood" in the current situation.

Keywords: Colonialism; Contemporaneity; Genre; Marcelino Freire; Post-colonialism.

\section{INTRODUÇÃO}

Os estudos pós-coloniais têm como princípios norteadores as instrumentalizaçóes de denúncias impostas pelas atitudes e olhares dos colonizadores europeus em detrimento das naçôes colonizadas, pelos quais a opressấo, a subversividade, o controle, a exploraçâo, a marginalizaçâo eram métodos de construçâo do projeto imperialista. Vale ressaltar que as práticas colonizadoras criaram terrenos férteis para propagar o sentimento de inferioridade/superioridade em diversos espaços, por muitos séculos, e manter o projeto de hegemonia e controle econômico a partir de um pequeno círculo europeu, ocasionando năo somente a degradaçâo de muitas naçôes, mas também, em alguns lugares como o Caribe, o extermínio de algumas populaçóes e línguas. Se o projeto imperialista europeu foi benéfico e escandalosamente lucrativo para uma meia dúzia de países do 'Velho Mundo', em contrapartida, este mesmo projeto foi profundamente desastroso e sanguinário para todos os demais países envolvidos no esquema, ainda que sem escolha ou vontade, aqueles que estavam no outro lado da moeda e vistos como simples instrumentos de manipulaçăo e fontes de recursos.

Entretanto, ao aludirmos à literatura pós-colonial, pode-se pensar em uma nova estética, onde os povos colonizados formam o esquadrăo de frente, trazendo à tona as atrocidades cometidas pelo colonizador, denunciando-as e possibilitando uma nova releitura e reescrita das obras imbuídas desse 'Olhar do Outro' sobre o outro e da subalternidade do sujeito que se diferenciava da cultura hegemônica, essa considerada superior, padrâo, correta, e única moldada de valores arquétipos.

Na medida em que as histórias eram contadas pela ótica do colonizador, a inferiorizaçăo ocorria de forma inescrupulosa à figura do colonizado, pois rotulavam-no como sujeitos sem cultura, sem religiâo e sem ideologia. No contexto, tem-se como estratégia de dominaçâo a outremizaçăo, como modulaçăo de imposiçăo da Cultura sobre a cultura, modificando-a, e fragmentando-a, e ainda se acopla a criaçăo dos estereótipos, caracterizando o colonizado de forma negativa nos aspectos físico, social, cultural e intelectual; outros aspectos podem ser referidos a etnografia, a hegemonia, o Outro/outro, o discurso, o olhar panóptico, centro e margem, entre outros, que se constituíram como diferenciaçáo de uma Populaçâo em marginalizaçăo da outra.

É a partir do cenário supradito, que a teoria e a crítica dos estudos pós-coloniais agregados a outros contribuintes como a crítica feminista e os estudos culturais, em especial tratando-se da questâo de gênero, que o estudo em tela objetiva realizar uma investigaçăo através dos contos "Alemăes vâo à guerra", "Yamami", "Vanicléia”, "Jéssica” 
e "Totonha", contidos nas obras BaléRalé (2004) e Contos negreiros (2005), refletindo a figura da mulher dentro do contexto do colonialismo, do pós-colonialismo e contemporâneo, em visto de sua dupla exploraçăo, subordinaçăo e inferiorizaçăo. No entanto, năo nos deteremos nesse sujeito (a mulher) somente enquanto ser colonizado, mas de seu processo de exploraçăo, balbuciamento, até sua posiçấo de lugar como sujeito que fala e tem voz, interroga, náo se deixa subordinar, năo se entrega ao contexto de imposiçăo, mas que se coloca como recusa e construtora de sua própria vida.

\section{A RELAÇÃO ENTRE OS ESTUDOS PÓS-COLONIAIS E O FEMINISMO: SILENCIAMENTOS E RESISTÊNCIAS}

Se pensarmos historicamente, em detrimento dos acontecimentos que emanaram a partir da década de 1960, tem-se entăo, o pós-colonialismo e o feminismo comungando, pois o imperialismo e o patriarcalismo sujeitam o colonizado e a mulher. Por conseguinte, é no ensejo das experiências vivenciadas pelo colonizado e pela mulher que surgem como argumento o pós-colonialismo e o feminismo. Os dois urgem e se validam do mesmo discurso, partindo da política de representatividade e da identidade, operados principalmente pela linguagem. Neste sentido, o texto literário é de grande valia, pois cabe a ele espaço de denúncia, revide e contra-ataque (pela escrita).

O pressuposto supradito refere-se à dialética que se desdobra em muitos escritos, aquele que creem no fato da mulher ter sido duplamente colonizada, o que pode-se pensar de forma vertical e horizontal, ou seja, colonizada pelo colonizador e pelo próprio colonizado (sexo masculino). A colônia năo se torna somente ambiente recémdescoberto e explorado pelo colonizador, mas alegoria da própria imagem da mulher. Navegando "[...] na história do Brasil, a mulher sempre foi relegada ao serviço do homem, ao silêncio, à dupla escravidăo, à prostituiçăo ou a objeto sexual [...]" (BONNICI, 2009, p.266). No panorama dos romances brasileiros, como "O cortiço" (1890), de Aluízio Azevedo, "Senhora" (1874), de José de Alencar, “Dom Casmurro" (1899), de Machado de Assis e em diversos romances de Jorge Amado, entre eles, "Tereza Batista Cansada de Guerra" (1972), propaga-se o perfil da mulher analogicamente enquanto subalterna e objeto. Nesse sentido, os dois discursos têm como objetivo a inserçăo da mulher na sociedade.

Historicamente, a mulher sempre foi considerada uma figura inferior ao homem, submetida aos trabalhos domésticos, sendo excluída dos trabalhos intelectuais. Figura submissa ao homem, vivia com o intuito de procriar e servir ao mesmo, năo tendo direito à educaçăo, pois lhe era negada. Dessa forma, ela estava destinada ao objetivo de manter o bem-estar da família e satisfazer os desejos de seu marido, acarretando, assim, o seu enclausuramento num ambiente patriarcal. Os direitos náo lhes eram reservados (como ainda náo o săo em muitas naçóes do globo), os anseios e desejos que elas gostariam que se concretizassem eram renegados.

Nessa perspectiva, a mulher era sempre considerada como "Outro". Destaca Beauvoir (1980, p. 179):

A HISTÓRIA mostrou-nos que os homens sempre detiveram todos os poderes concretos; desde os primeiros tempos do patriarcado, julgaram útil manter a mulher em estado de dependência; seus códigos estabeleceram-se contra ela; e assim foi 
que ela se constituiu concretamente como Outro. Esta condiçâo servia os interesses dos homens, mas convinha também a suas pretensōes ontológicas e morais.

A história marca esse episódio, no qual o homem se vê como detentor de todo o poder, ditador do que deveria ser feito, colocando a mulher como objeto de domesticaçăo. Entretanto, as mulheres começaram a reivindicar, lutar, buscar e conquistar seus direitos, principalmente no que condiz a sua relaçăo nas questôes pertinentes ao âmbito social. Com o passar dos séculos, compreende-se que a mulher veio ganhando seu espaço e sendo destaque em vários âmbitos. Ressalta Zolin (2009, p. 217):

Desde a década de 1960, com o desenvolvimento do pensamento feminista a mulher vem se tornando objeto de estudo de diversas áreas de conhecimento, como a Sociologia, a Psicanálise, a História e a Antropologia. Também no âmbito da Literatura e da Crítica Literária, a mulher vem figurando entre os temas abordados em encontros, simpósios e congressos, bem como se constituindo em motivo de inúmeros cursos, teses e trabalhos de pesquisa.

Nessa escala de importância, a mulher passa de figura inferior à figura igualitária, ou seja, tem direitos e faz parte da sociedade enquanto ser participante e atuante no meio em que vive. Entretanto, nem sempre dentro dessas áreas a mulher foi respeitada, porque "a fim de provar a inferioridade da mulher, os antifeministas apelaram năo somente para a religiăo, a filosofia e a teologia, como no passado, mas ainda para a ciência: biologia, psicologia experimental, etc." (BEAUVOIR, 1980, p. 17). Para exemplificar, quando a questăo religiosa, os homens apoiavam-se na serventia da mulher à ele, visto que lhe deviam respeito e obediência total, sem o mínimo de questionamento e participação, já que ELE era reconhecido como o detentor da sabedoria, e o embasamento se encontrava nas passagens bíblicas; o tangente ao enfoque biológico, a mulher, pela tradiçâo patriarcal era subjugada quanto ao seu corpo, sendo o seu destino, neste caso, os papéis sociais destinados à ela, sâo visualizados como um fator de ordem natural; e por último a linguagem atribuída a personagem feminina, à qual, construía-se a partir da subordinaçăo ao homem e da diferenciaçấo entre a questăo de gênero e classe social.

É importante ressaltar que o feminismo foi um movimento de luta criado e liderado por mulheres contra a sociedade sexista, em busca de direitos igualitários para ambos os sexos. Este marcou de forma positiva esta época, modificando as formas de pensar de viver da sociedade.

Este também causou um grande impacto, tanto nos âmbitos das instituiçóes sociais e políticas, quanto nos hábitos e costumes do cotidiano, ampliando a atuaçâo da mulher nas questóes públicas, sendo repercutido de forma marcante em toda a sociedade. O feminismo representa uma crítica à desigualdade social de sexo, num panorama sociológico de gênero, promovendo os direitos feministas.

No campo literário, a questăo feminista teve seu marco inicial na publicaçăo de Sexual Politics em 1970, tese de doutorado de Kate Millet. A partir desta publicaçăo, muitas mulheres começaram a publicar suas críticas literárias feministas, deixando sua posiçăo de inferioridade e passando a surgir como escritoras dentro da literatura; ou seja, praticando elas mesmas um conceito típico do pós-colonialismo - a subjetificaçăo. Neste sentido, as mulheres năo aceitam mais a condiçăo sexista imposta pelos homens, pela qual seriam meros objetos, e assumem de vez seu papel social, cultural e 
político de sujeitos que săo. Tendo como reflexâo que "[...] a constataçăo de que a experiência da mulher como leitora e escritora é diferente da masculina implicou significativas mudanças no campo intelectual, marcadas pela quebra de paradigmas e pela descoberta de novos horizontes de expectativas" (ZOLIN, 2009, p. 218).

A mulher deve muito ao movimento feminista, visto que passou de uma figura meramente explorada para uma figura de estudo e de grande importância no que condiz ao espaço literário. Salienta Zolin (2009, p. 218):

\begin{abstract}
Nas últimas décadas, muitas facçôes críticas defendem a necessidade de se considerar o objeto de estudo em relaçăo ao contexto em que está inserido; de alguma forma, tudo parece estar interligado. No que se refere à posiçăo social da mulher e sua presença no universo literário, essa visăo deve muito ao feminismo, que pôs a nu as circunstâncias sócio-históricas entendidas como determinantes na produçăo literária. Do mesmo modo que fez perceber que o estereótipo feminino negativo, largamente difundido na literatura e no cinema, constitui-se num considerável obstáculo na luta pelos direitos da mulher.
\end{abstract}

Este ester eótipo foi criado como uma perspectiva de demonstrar a relaçăo de poder. Poder que devinha de toda forma do autoritarismo legado ao homem. O olhar literário ao objeto mulher está ligado ao processo que o feminismo repercutiu, e é importante citar que este estereótipo náo estava presente em dado momento só na literatura, mas em outros meios de comunicaçăo. Quando se trata da relaçáo de poder, considera-se que quando reflete-se sobre a crítica literária feminista, entende-se que ela tem um cunho político. Comenta Zolin (2009, p. 218):

[...] também a crítica literária feminista é profundamente política na medida em que trabalha no sentido de interferir na ordem social. Trata-se de um modo de ler a literatura confessadamente empenhado, voltado para a desconstruçâo do caráter discriminatório das ideologias de gênero, construídas, ao longo do tempo, pela cultura. Ler, portanto, um texto literário tomando como instrumentos os conceitos operários fornecidos pela crítica feminista implica investigar o modo pelo qual tal texto está marcado pela diferença de gênero, num processo de desnudamento que visa despertar o senso crítico e promover mudanças de mentalidades, ou por outro lado, divulgar posturas críticas por parte dos(as) escritores(as) em relaçăo às novas convençôes sociais que, historicamente, têm aprisionado a mulher e tolhido seus movimentos.

Sabe-se que levaram séculos para a reconstruçâo da ideologia criada em relaçâo ao gênero, isso se deu por uma cultura criada na sociedade da época. Essa quebra de paradigma relacionado ao gênero feminino se deu a partir de uma construçăo que implicou em mudanças de atitudes sociais e culturais.

Considera-se as mudanças sócio-históricas como sendo um fator importantíssimo ao relacionar a produçăo literária feminina. Muitas discussóes já vêm sendo feitas desde as décadas de 1970 acerca do espaço negado à mulher na sociedade e o reflexo disso no campo literário. Todos estes debates têm como objetivo romper com a tradiçâo criada em relaçăo à mulher, no qual ocupava um papel secundário a do homem. Entende-se que tal implicatura leva a um questionamento quanto aos cânones críticos e literários. Nessa mediaçăo "[...] a crítica feminista trabalha no sentido de desconstruir a oposiçâo homem/mulher e as demais oposiçóes associadas a esta, numa espécie de versăo do pós-estruturalismo" (ZOLIN, 2009, p. 218). 
Quanto à história, relata-se ainda que a figura da mulher foi se construindo com o tempo, em diferentes lugares. Quando se trata dos Estados Unidos, compreende-se que o feminismo só entra no cenário político por volta da metade do século XIX, das reivindicaçōes feitas através de campanhas pela igualdade legislativa. Já na Inglaterra, ainda entre os séculos XIX e XX, estes eram marcados pela indiferença à mulher. Segundo Zolin (2009, p. 220):

Na Inglaterra, a condiçấo da mulher na Era Vitoriana (1832-1901) foi tenazmente marcada por diversos tipos de discriminaçóes, justificadas com o argumento da suposta inferioridade intelectual das mulheres, cujo cérebro pesaria 2 libras e 11 onças, contra as 3 libras e meia do cérebro masculino. Resulta disso que a mulher que tentasse usar seu intelecto, ao invés de explorar sua delicadeza, compreensăo, submissăo, afeiçáo ao lar, inocência e ausência de ambiçăo, estaria violando a ordem natural das coisas, bem como a tradiçâo religiosa. Eram esses os valores apregoados pela rainha Vitória em suas cartas e por suas súditas em guias vitorianos como The Female Instructor (A professora), de autor anônimo, ou The Women of England (As mulheres da Inglaterra), de Sarah Stickney Ellis, publicado em 1839 [...].

No entanto, apesar das mulheres năo terem acesso à lei, percebe-se que nas práticas sociais a realidade era outra, pois a maioria năo queria se submeter ao modelo organizacional social da época. Năo submetendo-se ao enclausuramento familiar, as mulheres trabalhavam fora como costureiras, domésticas ou operárias. Assim, a prerrogativa determinada pela era vitoriana na Inglaterra servia como respaldo para uma minoria, ainda que visasse moldar um padrăo comportamental feminino para todo o período.

Quando toma-se em reflexăo a questăo da mulher no século XIX, vai-se criando uma personificaçăo da mulher diferenciada, visto que o feminismo repercutiu como forma inovadora e movimento plausível no âmbito social e político. Destaca Zolin (2009, p. 219-220)

Seja como for, mesmo que se entenda que o feminismo esteja restrito aos últimos dois ou três séculos, trata-se de um movimento político bastante amplo que, alicerçado na crença de que, consciente e coletivamente, as mulheres podem mudar a posiçấo de inferioridade que ocupam no meio social, abarca desde reformas culturais, legais e econômicas, referentes ao direito da mulher ao voto, à educaçăo, à licençamaternidade, à prática de esportes, à igualdade de remuneraçăo para funçăo igual etc., até uma teoria feminista acadêmica, voltada para reformas relacionadas ao modo de ler o texto literário.

Tudo isso contribuiu para que a mulher viesse a se tornar uma figura importante dentro dos textos literários e também que se expandisse a formaçăo de uma tradiçâo literária de autoria feminina tanto na Europa quanto nas Américas, revertendo, nesse sentido, os valores criados pela tradiçâo literária masculina. Nessa perspectiva, o final do século XIX proporcionou uma nova visăo da mulher na literatura, năo sendo mais exposta e submissa ao processo de inferioridade ao homem, compreendendo sua capacidade de empreender e realizar mudanças no meio social e político.

\section{RETRATOS DA MULHER NOS CONTOS FREIRIANOS}

A mulher, figura emblemática nos escritos de Marcelino Freire, participa de forma indireta ou direta na construçáo da história ficcional, dependendo do contexto em que se insere. No entanto, apesar das grandes transformaçōes sociais e culturais, ela ainda 
é subjugada de forma dissimulada ou até mesmo expositiva, pela conjuntura atual. 0 que devemos destacar no panorama mundial é que o sujeito feminino ainda vive as grandes mazelas da violência e da subordinaçáo derivada do homem, principalmente quando este, ao tomar um posicionamento patriarcal, visa a mulher como objeto, relegada a num ambiente submisso, de resignaçăo, atestada como mero instrumento de satisfaçăo sexual.

Ao analisar os contos freirianos nos livros BaléRalé e Contos negreiros, percebermos as diversas contendas vivenciada pelas mulheres, independentemente de sua cor ou classe social. É importante lembrar que o contexto contemporâneo ainda guarda e carrega os grandes dramas vivenciados pelas mulheres desde os tempos mais remotos. O que se vislumbra ainda é uma guerra desnudada dessa personagem quanto à incompreensăo sobre a ideia de gênero.

Tal representaçăo fica evidente no Canto IV "Alemáes văo à guerra", do poema "Navios Negreiros":

Alô, Johann. Johann. Como as negras do Nepal, tem. Das Ilhas Virrgens também. É só irr. Feito as mocinhas da Guiana. Da prraia do Pina, depois do hotel, é só irr. Prreparra a mala, Johann. Deixa a mala pronta.

$[\ldots]$

Nosso dinheirro salvaria, porr exemplo, as negrrinhas do Haiti. Barratas como as negras de Burrunti. Trouxe uma parra aqui, lembra? Faz tempo que eu trouxe uma parra aqui.

Ajudei a prreserrvarr, no meu pescoço os dentes de marfim. Hoje, ela ganha ensinando ao povaréu de Berrlim. Em Mönchengladbach, dança. Ganha a sorrte no samba (FREIRE, 2005, p. 37).

Diante da situaçăo vê-se o tranquilo diálogo ao referirem-se às personagens femininas, tecendo-lhes falas com olhar objetificador. A mulher negra (em referência) estereotipada de forma descartável, e além disso, "salva" pela "solidariedade" do estrangeiro, delegando as localidades citadas (Nepal, Guiana, Rio de Janeiro, Salvador etc.) como cenários de exploraçâo sexual, por isso o motivo de deixar "a mala pronta". É perceptível a voz do personagem masculino, sobrepondo o silenciamento da mulher que se vê ser explorada, trocada, descartada e exaltada pela "educaçáo" proporcionada pelo Outro. Na guerra, quem se utiliza dos maiores artifícios săo os estrangeiros, haja vista o olhar depreciativo aos países de Terceiro Mundo, vistos continuamente como massa de manobra e fonte de recursos naturais e humanos. A tal proposta 'catequizadora e salvadora' do europeu serviu tâo somente para flagelar e degradar milhóes de indivíduos em todo o planeta e, neste cruel estratagema de conquista e manutençăo do poder, as mulheres negras e indígenas sâo as que mais sofreram e ainda sofrem espoliaçăo de todo o tipo.

Comungando de semelhante pensamento, no Canto XVI "Yamami", os personagens, turistas que vêm ao Brasil e passam pelo Amazonas, e outras localidades náo se preocupam com as belezas vistas, mas somente com a indiazinha encontrada num dos passeios turísticos:

\section{$[\ldots]$}

Fodam-se os índios do Brasil. Toquem fogo na floresta. Vâo à merda.

Que turista é você? E a febre amarela?

Só lembro de Yamami. 
Yamami.

Sempre gostei de crianças. Aqui é proibido.

Yamami, meu tesouro perdido. [...]

$[\ldots]$

Você chega, estanca seu olhar em volta, seu olhar em cada buraco, estopa, saco. E vê no mercado. Um extenso mercado no centro da cidade. A puta que você vê tem onze anos. Ou menos. Parece. Năo cresce. Vive seminua, sujinha e deliciosa, esperando a lotaçăo da balsa. Há tucanos para vender. E corpos.

Vivi Yamami lá.

Indiazinha típica de uns 13 anos. [...] Virei um canibal, de repente. Năo é tăo deliciosa a carne de tamanduá-bandeira (FREIRE, 2005, p. 105-106).

A năo importância expressa no discurso do estrangeiro (homem) sobre as belezas naturais existentes no Brasil é evidente; o que desperta interesse ou lembranças desse local ignorado por ele é somente Yamami, criança/adolescente e índia. Evidencia-se a exploraçăo sexual infantil, temática pouca suscitada, discutida e ignorada na prosa brasileira, lembrada no momento através da personagem citada. E ao ir mais a fundo, pode-se pensar na personagem Yamami como a própria Amazônia, que há muitos anos foi explorada pelo colonizador. Yamami é, nesta perspectiva, uma representaçáo metonímica do lugar que habita, sendo ela e solo amazônico frutos de usurpaçâo e dano alheio, num doentio círculo vicioso no qual, pela miséria da menina, a luxúria e a ambiçâo do estrangeiro de regozijam e se alimentam.

No excerto, a palavra mercado é mencionada, ao qual remete a um ambiente onde se vende mercadoria, isto é, Yamami, mercadoria à venda, por isso, o personagem cita que há, além de animais, "corpos" para vender. Além dessa horrenda cena, ele igualmente a compara com um animal ao comentar "Nâo é tăo deliciosa a carne de tamanduá-bandeira". O personagem vira um verdadeiro canibal e a mulher um objeto-animal, vista como "carne' a ser saboreada pelo homem; em outro fragmento do mesmo conto o turista revoga o destino de Yamami ao pronunciar "[...] minha meretriz, o meu turismo" (FREIRE, 2005, p. 107).

Nos dois contos, a culpa da exploraçăo sexual visualizada como situaçóes de estupro é advogada à figura feminina, como se se reafirmasse muitas expressōes (mal) ditas em que a mulher usa a sexualidade para conseguir o que quer. Isso nos remete a vários discursos atuais, como por exemplo, o caso da moça que fora estuprada por um grupo de mais de trinta homens, e, diante do qual, percebe-se a reaçăo de vários jovens de ambos os sexos que justificam o fato: "o que ela estava fazendo naquele local em determinado horário?", "ela era usuária de drogas", em detrimento de muitas outras vozes que querem justificar a atrocidade da violência ocorrida. Levanta-se a bandeira de que o estupro é errado, mas se justifica socialmente esta barbárie pelas indagaçōes e afirmaçóes correntes.

A generalizaçăo da normalidade toma conta do pensamento humano como se as negrinhas do Haiti e do Burrunti e Yamami, do Amazonas, gostassem ou quisessem ser exploradas, invadidas, extorquidas. Esse processo no qual a mulher fora explorada por muito tempo e ainda é, tornou-se uma prática tăo corriqueira que passa muitas vezes despercebidas pelo olhar humano.

Se repetimos uma coisa várias vezes, ela se torna normal. Se vemos uma coisa com frequência, ela se torna normal. Se só os meninos săo escolhidos como 
monitores de classe, entăo em algum momento nós todos vamos achar, mesmo que inconscientemente, que só um menino pode ser o monitor da classe. Se só os homens ocupam cargo de chefia nas empresas, começamos a achar "normal" que esses cargos de chefia só sejam ocupados por homens (ADICHIE, 2015, p. 18).

Logo, caímos e cometemos o mesmo erro de pensar que tudo que é obvio para alguns é também para todos. Nesse caso, ao vivenciar um contexto no qual a mulher é explorada sexualmente, esta situaçăo firma-se como normalidade a tal ponto de passar despercebida tal realidade descabida.

A mulher năo está submetida apenas ao olhar exploratório sexual que se evidencia como uma forma de violência, mas vivencia esta realidade de outras diversas facetas, como a psicológica, física, simbólica, verbal, doméstica, entre outras.

É de relevo a presença constante da violência nos contos de Freire, no canto III "Esquece", a palavra Violência aparece oito vezes e todas no início do excertos, caracterizadas pelo V maiúsculo. No canto V"Vanicléia", vê-se a condiçăo desta, sofrendo com tal intensidade que prefere viver em outras condiçóes:

U, hum. Agora ter que aguentar esse bebo belzebu. O que é que ele me dá? Bolacha na desmancha. Porradela na canela. [...]

[...] Qual é a minha esperança com esse marido barrigudo, eu grávida? Que leite ele vai cosntruir?

$[\ldots]$

Agora que valor me dá esse belzebu? Quanto vale ele ali, na praça? "tirar sangue de mim. Cadê meus dentes? Nem vê que tô esperando uma criança. Agora, disso ninguém tem ciência. Ninguém dá um fim.

Mulher como eu ser tratada assim (FREIRE, 2005, p. 41-42).

Vanicleía era prostituta, mas já estava cansada de viver a vida boêmia, pensa entăo viver uma outra realidade, casar-se e ter filhos, como "toda" mulher sonha, no entanto, ao transpor-se para o outro contexto, encontra e vive num ambiente totalmente hostilizador, violento e náo acolhedor, o que lhe remete entâo o pensamento ao passado quando se prostituía, pois era tratada melhor. De tanto sofrer com bruta agressâo, se sua filha for menina, resolve que vai ensiná-la a seguir os mesmos passos da vida passada. O personagem masculino "tira sangue" e descaracteriza a mulher tirando dela todos os dentes. Relacionando o substantivo próprio Vanicléia ao substantivo concreto Violência, tem-se uma relaçáo do emprego da letra V, que remete aos atos sofridos pela personagem. A violência em torno da mulher está tâo impregnada no contexto social contemporâneo, e muito tem a ver com a própria forma de colonizaçăo dos lugares mais violentes às mulheres, que as próprias mulheres náo julgam certas formas cotidianas de violência e, muitas vezes, colaboram com a manutençâo de atos de violência porque julgam ser normais tais 'atitudes de homens'. Isso é tâo comum que seria difícil encontrar alguém no Brasil, por exemplo, que nâo tenha conhecido alguma mulher que já tenha apanhado de um companheiro. Dolorosamente, sabe-se que muitas delas prosseguem a vida com eles, em um literal processo de 'dormir com o inimigo'.

Em BaléRalé, no conto "Jéssica", a mesma sofre violência pelo "cara" que matou a sua filha, insulta-a de vagabunda, mordendo sua língua e pedindo para ela "ciscar" no ouvido dele, ou seja, suspirar baixinho. Mas quando pensamos no verbo "ciscar", 
logo o relacionamos a um animal, neste caso, a galinha. Jéssica sofre com esta grande opressāo:

[...] disse assim respire fundo cravou os dentes no meu pescoço arranhou as minhas costas chegou no meu seio durinho devagar e forte devagar e forte amarrou a máo nos meus cabelos [...]

$[\ldots]$

[...] pensei em gritar que náo queria mas náo devia ele me batia com o pau molhado a cabeça sangrenta acesa do seu mastro e gritava que eu dissesse baixo póe tudo seu desgraçado me fode nunca vi animal assim tăo macho cheirando a cavalo óleo asfalto vindo para cima de meu traseiro rápido passou saliva nos dedos primeiro enfiou um e aí dois dedos uma das máos alisando a minha buceta fique calma calminha fiz o que ele mandava empurrou sua vara até o meio vara grossa como uma árvore derrubada vara grossa como uma tempestade [...] (FREIRE, 2004, p. 101-102).

O fragmento externa a crueldade, a brutalidade praticada pelo personagem homem que năo é identificado; Jéssica, além de perder sua filha assassinada, e provavelmente estuprada também pelo mesmo cara, agora se vê na mesma situaçăo. Algumas palavras no conto têm bastante peso semântico, como: cravou, amarrou, tempestade, dentre outras. Demonstrada assim, a verdadeira "tempestade" na vida de uma mulher quando passa pela situaçáo do estupro.

Na continuaçâo do conto, ela sofre diversas "retaliaçóes", é chamada de piranha quatro vezes, gozam e mijam nela, e como ela mesma diz, ele veio "[...] feito vento violento [...]" (FREIRE, 2004, p. 103). Somente depois de sua partida ela se pôs a chorar "compulsivamente e assustadoramente", de onde resulta entâo o desfecho, "[...] doutor por favor diga o que devo fazer que nome dar a essa filha que năo quero ver nascer? [...]" (FREIRE, 2004, p. 103). O conto é um desabafo/desafogo, sem pontuaçăo durante todo o texto, pois inicia-se como se você inspirasse e finaliza com um ponto de interrogaçấo, como se você expirasse, nâo como símbolo de alívio, mas como desabafo, hora transferido ao choro irrefreável. A "tempestade" náo veio com ventos amenos, mas com ventos violentos e acabou por deixar calamidades terríveis a uma vida.

A falta de pontuaçăo no conto também expressa o momento agonizante (falamos do estupro) que vivem tantas mulheres dos quatro cantos do mundo, desejam que nâo se tenham "paradas" ao passar por essa tormenta, ou seja, que se finalize logo, pois têm seus corpos "estraçalhados" como copos de vidros caindo ao châo, além disso, podemos utilizar-nos do ponto de interrogaçăo no final do conto, porque isso frisa a realizaçăo de uma outra interrogaçâo ou interrogaçóes, por que a mulher ainda passa por tal situaçăo? Por que vivencias tais atrocidades? Por que é vista como mero objeto sexual? Por que náo é respeitada e náo é valorizada nos mais diversos contextos? Por que matam-na "invadindo" seu corpo, causando várias sequelas e hematomas que duram por toda a sua vida? ... É pertinente pensar que o conto năo termina com um ponto final, alude entăo a atrocidade ocorrida à figura feminina.

Muitos séculos se passaram, porém as barbáries contra a mulher na contemporaneidade săo visíveis, podemos cair na dicotomia vazia e expressar que as coisas para as mulheres nâo sâo difíceis e diferentes em pleno século XXI em relaçáo aos homens. Vale lembrar que năo vivemos em um espaço hegemônico, o hibridismo é um fator de essencialidade em nossa formaçăo cultural. A situaçăo de distinçăo de gênero é 
muito real em nossa sociedade, um exemplo a destacar é a situaçăo de Adichie, ao relatar uma de suas experiências:

[...] Abri a bolsa, peguei o dinheiro e lhe dei. E ele, feliz e grato, pegou o meu dinheiro, olhou para o meu amigo e disse: "Muito obrigado, senhor!". Surpreso, Loius me perguntou: "Por que ele está me agradecendo? Nâo fui eu quem deu o dinheiro". Percebi entăo, pela expressăo de meu amigo, que a ficha tinha caído. Para o flanelinha, qualquer dinheiro que eu pudesse ter certamente provinha de Louis. Porque Louis é homem" (ADICHIE, 2015, p. 21-22).

É perceptível que a ideia de gênero ainda prevalece e nossas ideias sobre tal deixam a desejar. Dotados de inteligência, criativos, astutos, inventivos, săo o homem e a mulher, todavia essa diferenciaçâo é prorrogada até pela própria biologia, ao prescrever as diferenças de quantidades de hormônios, órgâo sexuais diferentes, em um poder ter filho e outro nâo, quantidade de testosterona, dentre outros aspectos. Ainda há diferenças, como por exemplo, 52\% da populaçâo mundial é feminina, porém os maiores cargos, sejam de prestígio ou de poder, estăo nas măos de homens. Abre-se entâo um largo bloco de diferenciaçăo.

Apesar desse conjunto de incompreensăo de espaços, do coral de silenciamentos de vozes da mulher, as poucos văo se "rasgando as cortinas", e elas văo se apresentando, mas ainda de forma tímida e restrita. Os contos de Freire aqui apresentados fazem essa composiçấo aos poucos, primeiro "Alemâes vâo à guerra" e "Yamami", as vozes sâo traçadas pelos homens, e as mulheres apenas aceitam "caladas" sem possíveis denúncias, segundo Vanicléia e Jéssica, embora as histórias sejam contadas por elas. As mesmas começam a obter espaços e vozes, no entanto somente balbuciam.

Ao adentramos no canto XI "Totonha", contido em Contos negreiros, percebemos que as apresentaçóes mudam, o espaço, antes negado à mulher, agora se subverte, é invadido, ou melhor, o espaço é questionado, e a voz da mulher começa a tomar outra tonalidade e a ter outro fôlego. No canto/conto, incialmente podemos fazer uma interpretaçâo superficial ao dizer que ela, a Totonha, năo quer aprender a ler, ou continuar em sua vida simplista, mas precisamos ir além dessa perspectiva e olharmos nas entrelinhas do texto.

Totonha dispensa a possibilidade de "ensino" colocado à sua disposiçâo e usa a sua fala para desdenhar e ironizar o governo atuante:

[...]

O governo me dê dinheiro da feira. O dente o presidente. E o vale-doce e o valelinguiça. Quero ser bem ignorante. Aprender com o vento, tá me entendendo? Demente como um mosquito. Na bosta ali, da cabrita. Que ninguém respeita mais a bosta do que eu. A química (FREIRE, 2005, p. 79).

Totonha utiliza-se de sua "ignorância" para criticar o dominante e ressalta que saber ler e escrever é "[...] pra gente que é moço. Gente que tem ainda vontade de doutorar. De falar bonito. De salvar vida de pobre [...]" (FREIRE, 2005, p. 79). Ao ler nas entrelinhas observamos a revolta dela com muitas pessoas instruídas pelo estudo, mas que todavia se utilizam dessa sabedoria/ignorância para usurparem e năo para melhorarem a sociedade e o espaço em que vivem, năo está apenas denotando sua velhice ou "invalidez" para tal atividade, mas que na sua simplicidade compreende e percebe o mundo a sua volta. Destacamos: 
Só para o prefeito dizer que valeu a pena o esforço? Tem esforço mais esforço que o meu esforço? Todo dia, há tanto tempo, nesse esquecimento. Acordando com o sol. Tem melhor bê-á-bá? Assoletrar se a chuva vem? Se năo vem?

Morrer já sei. Comer, também. De vez em quando, ir atrás de preá, caruá. [...]

$[\ldots]$

[...] Coisa mais sem vida é um nome assim, sem gente. Quem está atrás do nome nâo conta?

$[\ldots]$

Năo preciso ler, moça. A mocinha que aprenda. $O$ prefeito que aprenda. $O$ doutor. $O$ presidente é que precisa saber ler o que assinou. Eu é que năo vou baixar a minha cabeça para escrever.

Ah, năo vou (FREIRE, 2005, p. 80-81).

O ato de escrever exposto para Totonha năo é o ato de educar e sim uma imposiçăo emblemática ferrenha da cultura externa (doutrinadora). Ela năo se entrega de forma alguma ao (im)posicionamento, articula de todas as maneiras, desvinculando-se da artimanhas do neoimperialismo, do olhar panóptico. Nâo precisa implantar uma nova cultura, pois a sua já é válida para sobreviver, compreender e participar do mundo onde vive. Por isso, finaliza a sua fala, dizendo que năo vai baixar a cabeça e entregar-se àquele processo. Logo, năo se pode deixar a imposiçăo, o rechaço, a retaliaçấo, a exploraçâo ocorrer ao ser feminino, assim como as negrrinhas do Haiti e Yamami; balbuciar, e deixar-se ser violentada como Vanicléia e Jéssica; mas năo inclinar a cabeça como Totonha.

\section{CONSIDERAÇÕES FINAIS}

A pesquisa arrolada mostrou um panorama geral da visâo do Outro sobre o outro, em destaque a figura da mulher, como proposto no objetivo. A partir do estudo compreendeu-se que a crítica pós-colonial, feminista e de gênero, săo ferramentas fundamentais para posicionar-se frente às atitudes que cunham o subjugamento daqueles que encontram-se à margem dos padróes estabelecidos pelo "Centro", ora apesar de séculos se passarem, ainda prevalece nos mais variados contextos a inferiorizaçáo e subalternizaçâo da mulher.

Năo só na escrita e na construçăo de obras coloniais, como pós-coloniais e ainda nas contemporâneas, a mulher ainda é retratada e sujeitada a muitos poderios e padróes vigentes, ocorrido pela postura advinda da conjuntura social e da construçăo feita a base de estereótipos e objetificaçăo. Destacam-se essas posturas pelo seguinte vetor: apesar de terem se passados séculos de transformaçóes sociais, políticas, econômicas, e de um trabalho voltado na descolonizaçâo da mente, desmascaramento e conscientizaçăo, ainda se perduram em pleno século XXI (ano de 2017), muitas posiçôes, atitudes e práticas que minimizam e relegam os direitos femininos e sua importância na vida da sociedade.

Todavia, apesar da constituiçăo dos muitos silenciamentos existentes e dos mitos criados a respeito da mulher, de sua degradaçăo diante dos posicionamentos colocados em ambientes, onde a questăo de gênero só serve como pauta de subordinaçăo e de insignificaçăo, ela começa a constituir-se como Sujeito, isso é percebido por muitas 
manifestaçōes, como: os movimentos e manifestos ocorridos, as lutas pelo espaço e pelos direitos, na ficçăo podemos aludir à voz da mulher presente no cânone literário que se desenvolve rompendo os pressupostos masculinos, identidade, relevância de papel e da năo subordinaçăo săo discutidos nos textos ficcionais. A mulher se póe como escritora, adotando uma visăo pós-colonial e de gênero, desvelando as grandes mazelas de objetificaçấo e de năo entrega ao sistema ditatorial, atrelado às variantes desvalorativas da posiçăo da mulher.

A análise ainda nos possibilitou a construçâo de um "arquipélago", constituído de um mapeamento ao qual a mulher nos contos "Alemáes vâo à guerra" e "Yamami", estăo relegada as vozes, subnutrindo-se do silenciamento e da objetificaçăo, depois em "Vanicléia" e "Jéssica", temos os balbuciamentos impregnados de revoltas, mas ainda entregues aos contextos, deixam-se envolver-se pela abnegaçâo, por último "Totonha", destemida, năo alheia, firme, e consciente de sua posiçăo, năo curva a cabeça para o que lhe é imposto.

Por conseguinte, a figura da mulher contemporânea, apesar dos questionamentos, das lutas e da igualdade de gênero, ainda vivenciam as diversas mazelas oriundas ainda do contexto colonial, ainda mais quando se trata do subjugamento aos mais variados tipos de violência, entretanto, a resistência persiste e a insubordinaçăo aos paradigmas ainda constituídos sâo marcados pelas ensejos de igualdade, seja ela econômica, política ou social. 


\section{REFERÊNCIAS}

ADICHIE, Chimamanda Ngozi. Sejamos todos feministas. Traduçăo Christina Baum. - 1. ed. - Sấo Paulo: Companhia das Letras, 2015.

BEAUVOIR, Simone de. 0 segundo sexo: fatos e mitos. v. 1, trad. Sérgio Milliet. 4. ed. Rio de Janeiro: Nova Fronteira, 1980.

BONNICI, Thomas. Teoria e crítica pós-colonialistas. In: BONNICI, Thomas, ZOLIN, Lúcia Osana. Teoria literária: abordagens históricas e tendências contemporâneas. 3. ed. Rev. e ampl. - Maringá: Edduem, 2009.

FREIRE, Marcelino. BaléRalé. - 2. ed. - Sáo Paulo: Ateliê Editorial, 2004.

. Contos negreiros. - 9. ed. - Rio de Janeiro: Record, 2005.

ZOLIN, Lúcia Osana. Crítica Feminista. In: BONNICI, Thomas, ZOLIN, Lúcia Osana. Teoria literária: abordagens históricas e tendências contemporâneas. 3. ed. Rev. e ampl. Maringá: Eduem, 2009. 